\title{
Evaluation of high dilutions extract of pyroligneous on the development of Colletotrichum gloeosporioides
}

The aim of this research was to evaluate the fungitoxicity of high dilutions of tectonic (Tectona grandis) extract in mycelial growth, sporulation and germination of the fungus Colletotrichum gloeosporioides. In a completely randomized design with six dynamizations of the pyroligneousextract $(3,9,15,21,27$ and $33 \mathrm{CH})$ and three controls (distilled water, mother tincture, $30 \%$ hydroalcoholic solution) with four replicates each. All treatments were diluted to $0.1 \%$ in BDA medium. Mycelial growth rate index, relative percentage of mycelial development (PRD\%), inhibition of sporulation and spore germination (\%) were evaluated. The treatments did not differ among them for mycelial growth, percentage of spore germination and IVCM. The PRD and sporulation variables varied according to the dynamization, with a maximum reduction of $7 \%$ in PRD $(33 \mathrm{CH})$ and a $70 \%$ increase in sporulation ( 3 and $21 \mathrm{CH})$. The dynamized pirolenous extract did not present expressive fungitoxicity in the growth, sporulation and germination of $\mathrm{C}$. gloeosporioides.

Keywords: Homeopathy; Anthracnose; Mycelial Growth; Sporulation.

\section{Avaliação de altas diluições de extrato pirolenhoso no desenvolvimento de Colletotrichum gloeosporioides}

\begin{abstract}
A pesquisa visou avaliar a fungitoxicidade de altas diluições de extrato pirolenhoso de teca (Tectona grandis) no crescimento micelial, esporulação e germinação do fungo Colletotrichum gloeosporioides. Em delineamento inteiramente casualizado com seis dinamizações do extrato pirolenhoso $(3,9,15,21,27$ e $33 \mathrm{CH})$ e três testemunhas (água destilada, tintura mãe, solução hidroalcoólica $30 \%$ ), com quatro repetições cada. Todos os tratamentos foram diluídos a $0,1 \%$ em meio BDA. Avaliou-se as variáveis de crescimento micelial (cm), índice de velocidade do crescimento micelial (IVCM), porcentagem relativa de desenvolvimento micelial (PRD \%), inibição da esporulação e germinação dos esporos (\%). Os tratamentos não diferiram entre si para crescimento micelial, porcentagem de germinação dos esporos e IVCM. As variáveis PRD e esporulação oscilaram de acordo com a dinamização, com redução máxima de $7 \%$ na PRD (33 CH) e aumento de $70 \%$ na esporulação (3 e $21 \mathrm{CH}$ ). O extrato pirolenhoso dinamizado não apresentou fungitoxicidade expressiva no crescimento, esporulação e germinação de C. gloeosporioides.
\end{abstract}

Palavras-chave: Homeopatia; Antracnose; Crescimento Micelial; Esporulação.

Cleverson Rodrigues (iD)

Universidade Estadual Paulista, Brasil http://lattes.cnpq.br/5313148166874144 http://orcid.org/0000-0002-5892-421X cleverson-ro@hotmail.com

\section{João Aguilar Massaroto (it)}

Universidade do Estado de Mato Grosso, Brasil http://lattes.cnpq.br/4700819375531641

http://orcid.org/0000-0002-1845-4225 massaroto@unemat.br

\section{Grace Queiroz David Peres (iD)}

Universidade do Estado de Mato Grosso, Brasil http://lattes.cnpq.br/9003696340101394 http://orcid.org/0000-0001-6032-8516 grace@unemat.br

Dilânia Lopes de Matos
Universidade do Estado de Mato Grosso, Brasil
http://lattes.cnpq.br/6594744883985936
$\frac{\text { http://orcid.org/0000-0002-4993-9241 }}{\text { dilan lopes@hotmail.com }}$
Walmor Moya Peres@D
Universidade do Estado de Mato Grosso, Brasil
http://lattes.cnpq.br/8458149831212820
http://orcid.org/0000-0002-2249-8028
walmorperes@unemat.br
Oscar Mitsuo Yamashita (D)
Universidade do Estado de Mato Grosso, Brasil
http://lattes.cnpq.br/1761470950121024
http://orcid.org/0000-0001-6715-626X
yama@unemat.br

Marco Antonio Camillo de Carvalho (ID) Universidade do Estado de Mato Grosso, Brasil http://lattes.cnpq.br/2219061872247474 http://orcid.org/0000-0003-4966-1013 marcocarvalho@unemat.br
Referencing this:

RODRIGUES, C.; MASSAROTO, J. A.; PERES, G. Q. D.; MATOS, D. L.; PERES, W. M.; YAMASHITA, O. M.; CARVALHO, M. A. C.. Evaluation of high dilutions extract of pyroligneous on the development of Colletotrichum gloeosporioides. Revista Ibero Americana de Ciências Ambientais, v.11, n.2, p.69-77, 2020. DOI:

http://doi.org/10.6008/CBPC2179-6858.2020.002.0008 


\section{INTRODUCTION}

Preceded by the German physician Samuel Hahnemann in 1796, homeopathy, a term derived from the Greek ómoios, 'similar', and 'diseased', designates the therapeutic method based on the natural law of cure 'simila similibus curantur', that is, the similar will be healed by the like. The science of homeopathy is based on observation, experimentation and recognition and respect of the laws of life, its principles being applied to any level of complexity, acting on the vital force of being, restoring balance (ANDRADE et al., 2011).

Such science is based on the experimentation of highly diluted and sucussioned preparations whose phenomena meet the rigid criteria of modern science for being repeatable, quantifiable, describable, predictable, and cause-and-effect (CASALI, 2006). It is a science with its own philosophy, methodology and principles, being: similar similar healing; experimentation in the healthy organism; use of minimal doses and the single drug (FELITO et al., 2019a).

In general, these studies aim to verify the effect of homeopathic preparations, in the organism (vegetal, animal or microbiological), in order to restore their vital balance. The use of homeopathy in organic agriculture in Brazil has legal protection in Normative Instruction No. 07, published in the Brazilian Official Diary of the Union on May 19, 1999. This regulation establishes the norms of organic production in Brazil, thus allowing the use of homeopathic preparations by farmers, being recommended for both abiotic and disease control and pest control (ROLIM et al., 2005). According to Castro (2013), this knowledge made possible the use of homeopathy in several sectors, especially in agriculture and livestock, as well as a healthier treatment of diseased animals and plants, as well as a possibility to improve the production of plants and animals through induction of controlled pathogenesis. In this way, the use of homeopathy has become a valuable tool in agricultural production systems.

According to Rossi (2005), homeopathy applied to plants allows the control of pests and diseases caused by viruses, fungi and bacteria, in addition to increasing biomass production. These characteristics make homeopathy an ecological option for use in the field, totally according to the agroecological bases (FELITO et al., 2019b).

The use and efficiency of homeopathic treatments in the control of phytopathogens are reported by several authors. Khanna et al. (1976) also obtained significant results in the control of 'fruit rot', Fusarium roseum, in tomato, observing a prophylactic and curative action. Martín et al. (2005) evaluated the effect of homeopathic products on Fusarium solani, Rhizoctonia solani, Phytophthora parasitica, Alternaria brasicae under in vitro conditions obtaining satisfactory results in the control of the same with maximum inhibitions of $60 \%$, as well as Garbim et al. (2010).

In the preparation of homeopathic medicinal products, products of mineral, animal and/or vegetable origin are used in order to obtain the mother tincture for subsequent dilution and suction processes, as described in the Brazilian Homeopathic Pharmacopoeia (2011). For products of plant origin, tinctures of extracts, resins or liqueurs, such as the pyroligneous extract obtained from wood residue by means of condensation of the gases in the process of carbonization of wood, are generally used, presenting a wide 
potential of use in the agricultural environment (MACEDO et al., 2019).

The pyroligneousextract presents/displays numerous chemical compounds that confers to him characteristics of fertilizer, insecticide, fungicide among others. In its crude form, it presents the tar, both soluble and insoluble (ZANETTI, 2004), which compound that in high dosages and high time of exposure can generate serious damages to human (carcinogenic) health and the environment, not allowing its use in the organic production according to Normative Instruction No. 64, of December 18, 2008 - annexes VI and VIII (BRASIL, 2008).

Following the principles of homeopathy, the pyroligneousextract when dynamized could reduce the risks of contamination by still soluble tar and make feasible the use in organic agriculture, as an alternative measure of pest and disease control. In this way, the present research aimed to evaluate in vitro the fungistatic potential of high dilutions or dynamizations of the tectonic extract, Tectona grandis, in the mycelial growth, sporulation and spore germination of the fungus Colletotrichum gloeosporioides.

\section{MATERIALS AND METHODS}

The experiment was conducted at the Microbiology Laboratory of the State University of Mato Grosso, Alta Floresta, MT, Brazil. The research consisted of two stages, the first to verify the in vitro fungitoxic action of pyroligneousextract dynamizations on mycelial growth and sporulation of fungus $C$. gloeosporioides and the second to verify these dynamizations on spore germination.

Cashew leaves (Anacardium occidentale) with symptomatic picture of anthracnose disease were collected and taken to the Microbiology Laboratory in order to isolate the causative agent (C. gloeosporioides). Isolation was performed by adopting standard procedures for isolation in potato-dextroseagar culture medium (BDA), according to the method described by Alfenas et al. (2007).

After this procedure, the fungus was peeled to other plates, to obtain pure culture, keeping them in a germination chamber type BOD, with photoperiod of 12 hours at $25^{\circ} \mathrm{C}$. The pyroligneousextract was obtained from teak wood residue (T. grandis) in 2009, by the Wood Technology Laboratory of the State University of Mato Grosso, through the process of carbonization in a brick kiln at $180^{\circ} \mathrm{C}$.

The obtained pyroligneousextract remained conditioned in amber glass for little more than four years. This period was sufficient to occur to the decanting of the extract and its separation in phases, with the upper phase containing light oils, the pure pyroligneouscentral phase and the lower phase the tar (MIYASAKA et al., 2001). Thus, it was not necessary to use purification processes to eliminate possible compounds that could compromise its use, such as the high tar content.

With the separation of the extract in phases by the decanting process, the central part of the decanted liquid was used in the experiment, which comprises the pyroligneousportion, with pH around 3.05. To prepare the dynamizations (dilution + succussion) the pyroligneousextract of $T$. grandis was used as the mother tincture, following the Hahnemannian centesimal scale $(\mathrm{CH})$, that is, diluting one part of the preparation in 99 parts of the alcohol or water vehicle. For the experimental purposes, five drops of the mother tincture were diluted in $20 \mathrm{~mL}$ of vehicle (30\% alcohol) in $30 \mathrm{~mL}$ amber flasks, manually suctioning 
100 times, obtaining $1 \mathrm{CH}$ boosting; the process was continuously repeated until the $33 \mathrm{CH}$ dynamization.

In order to determine the antifungal activity of the homeopathic preparation, nine treatments were used, with six potencies or dynamizations $(3 \mathrm{CH}, 9 \mathrm{CH}, 15 \mathrm{CH}, 21 \mathrm{CH}, 27 \mathrm{CH}$ and $33 \mathrm{CH})$, chosen in a broad spectrum to represent the behavior of the dynamized extract plus three controls (distilled water, mother tincture, $30 \%$ hydroalcoholic solution).

The first step involved the tests of mycelial growth and sporulation, organized in a completely randomized design (DIC) with four replicates, with five Petri dishes in each repetition. The second step involved the inhibition test of spore germination, also in a completely randomized design (DIC), with four replications, with replication represented by a slide. The treatments, in the appropriate dynamizations were incorporated in BDA culture medium at a maximum temperature of $45 \circ \mathrm{C}$, in the concentration of $0.1 \%$ (TOLEDO et al., 2016), and then poured (10 mL) into $9 \mathrm{~cm}$ Petri dishes of diameter.

After solidification of the medium, a $10 \mathrm{~mm}$ disc of the pure culture, previously incubated for eight days in BDA medium, was deposited in the center of the plate; then these plates were sealed with plastic film and kept in the incubation room at $25 \pm 2{ }^{\circ} \mathrm{C}$, with photoperiod of 12 hours. The evaluations were carried out daily after 48 hours of inoculation, through measurements of the colonies diameter (mean of two diametrically opposed readings) with the aid of a millimeter ruler. In this way an average was obtained for each repetition of each treatment. This procedure was adopted until eleven Petri dishes $(50 \%+1$ of the total plaques) of the same treatment had minimal colonization of the surface of the medium.

The response variables obtained in the mycelial growth inhibition test were fungal growth, mycelial growth rate index, relative developmental percentage. Fungal growth was determined from the mycelial growth values, using the means of the last observation of each replicate of the mycelial growth treatment. The mycelial growth rate index (MGRI) was obtained from the averages of the daily values of mycelial growth of each treatment, as proposed by Oliveira (1991).

$$
M G R I=\sum(D-D a) / N
$$

At where; $\mathrm{D}=$ current mean diameter of the colony; $\mathrm{Da}=$ mean diameter of the colony from the previous day and $\mathrm{N}=$ number of days after inoculation.

In the determination of the relative percentage of development (RPD) a mathematical formula was used that represented the effect of the treatment on the fungal development, taking into account the control treatment, that would allow a relative development of $100 \%$. Thus the RPD was obtained from the means of the replicates, comparing the mean diameter $(\mathrm{cm})$ of the control (water) with the other treatments, using the formula:

$$
R P D=[(\varnothing \text { treatment }) /(\varnothing \text { control })] \times 100
$$

The sporulation inhibition test was performed at the end of the mycelial growth inhibition test. Five randomly chosen plates of each treatment were used to determine the concentration of spores per milliliter, in which $10 \mathrm{~mL}$ of sterile distilled water per plate were added. With the help of the Drigalski loop the friction was carried out on the mycelium to release the spores, followed by gauze filtration.

Then, a $100 \mu \mathrm{L}$ aliquot of the spore solution, composed of the five plates, was deposited in a Neubauer chamber and observed in optical microscopy in order to count the spores. The data were inserted 
into the CALIBRA software version 2011, made available by Embrapa, to determine the concentration of spores per milliliter (SANTOS et al., 2011).

To determine the inhibition of spore germination, $100 \mu \mathrm{L}$ aliquots were composed of $50 \mu \mathrm{L}$ of the spore suspension $\left(1.0 \times 10^{6}\right.$ spores $\left.\mathrm{mL}^{-1}\right)$ plus $50 \mu \mathrm{L}$ of each treatment (duly corrected to $0.1 \%$ of prepared in sterile distilled water) were placed together on a microscopy slide coated with a thin layer of $1 \%$ agar-water. The four slides of each treatment were incubated in a humid chamber in the dark, kept in BOD at $25^{\circ} \mathrm{C}$ for eight hours.

Then, with the optical microscope, the test was evaluated by means of a photographic record with a digital eyepiece with a magnification of 400x. Subsequently, a checkered mesh $(2 \times 2 \mathrm{~cm})$ was designed on these images in order to randomize the germinated spores count, counting 100 spores for each repetition. It was considered germinated the spore whose germinative tube had its length equal to or greater than the width of the spore.

The data obtained for growth, growth rate index and relative percentage of mycelial development and inhibition of spore germination were submitted to analysis of variance by the Tukey test at a significance level of $5 \%$, using the statistical program Sisvar (FERREIRA, 2014). For the inhibition of sporulation, a descriptive comparison of the observed means was made.

\section{RESULTS AND DISCUSSION}

There was no significant difference between treatments for inhibition of mycelial growth (Table 1). The 30\% hydroalcoholic solution and mother tincture showed identical growth, whose average growth was $3.34 \mathrm{~cm}$. With respect to the standard control (distilled water) an average growth of $3.53 \mathrm{~cm}$ was observed.

Table 1: Mycelial growth (cm), mycelial growth rate index (MGRI), relative percentage of mycelial development (RPMD) and germinated spore rate of Colletotrichum gloeosporioides submitted to homeopathic treatment in Hahnemann's centesimal scale of pyroligneousextract of teak (Tectona grandis), after eight days of incubation.

\begin{tabular}{|l|l|l|l|l|}
\hline Treatment & Mycelial growth (cm) & MGRI & RPMD (\%) & Germinated spore (\%) \\
\hline Sterile distilled water & $3,53 \mathrm{a}$ & $0,540 \mathrm{ab}$ & $100,0 \mathrm{~b}$ & $95,5 \mathrm{a}$ \\
\hline Mother tincture (EPT) & $3,34 \mathrm{a}$ & $0,525 \mathrm{a}$ & $94,7 \mathrm{ab}$ & $95,0 \mathrm{a}$ \\
\hline Hydroalcoholic Solution 30\% & $3,34 \mathrm{a}$ & $0,543 \mathrm{ab}$ & $95,9 \mathrm{ab}$ & $96,5 \mathrm{a}$ \\
\hline $\mathbf{3} \mathbf{C H}$ & $3,54 \mathrm{a}$ & $0,540 \mathrm{ab}$ & $100,4 \mathrm{~b}$ & $91,3 \mathrm{a}$ \\
\hline $\mathbf{9} \mathbf{C H}$ & $3,50 \mathrm{a}$ & $0,545 \mathrm{ab}$ & $99,1 \mathrm{ab}$ & $96,3 \mathrm{a}$ \\
\hline $\mathbf{1 5} \mathbf{C H}$ & $3,40 \mathrm{a}$ & $0,528 \mathrm{a}$ & $96,4 \mathrm{ab}$ & $96,8 \mathrm{a}$ \\
\hline $\mathbf{2 1} \mathbf{C H}$ & $3,47 \mathrm{a}$ & $0,538 \mathrm{ab}$ & $98,3 \mathrm{ab}$ & $96,5 \mathrm{a}$ \\
\hline $\mathbf{2 7} \mathbf{C H}$ & $3,40 \mathrm{a}$ & $0,550 \mathrm{~b}$ & $96,4 \mathrm{ab}$ & $98,3 \mathrm{a}$ \\
\hline $\mathbf{3 3} \mathbf{C H}$ & $3,30 \mathrm{a}$ & $0,540 \mathrm{ab}$ & $93,4 \mathrm{a}$ & $97,8 \mathrm{a}$ \\
\hline $\mathbf{C V} \mathbf{( \% )}$ & 3.01 & 1.83 & 2.70 & 3.14 \\
\hline
\end{tabular}

Same letters do not differ from each other by the Tukey test at $5 \%$ probability.

Similarly, Rodrigues et al. (2013), using dynamizations of the pyroclastic teak extract in the control of the fungus Ceratocistys fimbriata, verified that there was no significant difference between the dynamizations tested $(5 \mathrm{CH}, 15 \mathrm{CH}$ and $30 \mathrm{CH})$ and the mother tincture for mycelial growth in vitro. These authors reported a reduction of growth of $1.72 \mathrm{~cm}$ when compared to the control distilled water.

Various substances in the form of homeopathic preparations have also been tested in other phytopathogens. Behavior similar to that observed in the present study was reported by Carneiro et al. (2010) 
in the in vitro control of the fungus Alternaria solani, with no significant difference between all the dynamizations tested with homeopathic preparations of biotherapeutic $26,27,28,29$ and $30 \mathrm{CH}$ ) with the controls distilled water and hydroalcoholic solution 30\% This fungus belongs to the same group of diseases (Group V) of C. gloeosporioides according to McNew's classification in 1960, and are responsible for spots and crests, interfering in the same vital physiological process, that is, in photosynthesis. According to this author, diseases belonging to the same group present similar characteristics regarding the different phases of the cycle of pathogen-host relationships, often presenting identical measures for their control (BEDENDO, 2011).

The mycelial growth rate index (MGRI) presented a higher value $(0.55)$ for the $27 \mathrm{CH}$ dynamization, differing only from the mother tincture (Table 1). It was observed that the hydroalcoholic solution and mother tincture showed the same mycelial growth $(3.34 \mathrm{~cm})$, having a different speed index, but not significant, evidencing that the pyroligneousextract (mother tincture) did not interfere in the mycelial growth rate.

For the relative percentage of mycelial development (PRD), it was verified that, when compared to the standard control (distilled water), all treatments, except 3CH (100.43\%) dynamization, presented lower mean values (Table 1). However, only $33 \mathrm{CH}$ stimulation differed from water and $3 \mathrm{CH}$ treatments, with about 7\% less than both treatments, while the other treatments maintained a similar behavior with each other.

Rodrigues et al. (2013) reported a reduction of about $55 \%$ in the mycelial development of the fungus C. fimbriata, when submitted to the $15 \mathrm{CH}$ dynamization of the pyroligneousteak extract. Toledo (2009) reported in his experiments low reduction in the mycelial development of $A$. solani, around 3 to $18 \%$, varying according to the dynamization and the source material of the homeopathic preparation.

The observed behaviors for the three evaluated characteristics of mycelial development, with little or no significant difference between the controls and the dynamizations evaluated, may be related to the homeopathic principle of the minimum dose proposed by Hahnemann. In that any substance in its gross natural state manifests itself only as matter, that is, its doses cause effects interpreted by the laws of chemistry, due to the presence of molecules.

However, in the process of dynamizing the substance, the effects are interpreted by the laws of physics, since matter is condensed energy, and dynamization is the means of releasing that energy, acting in a non-molecular way (CASALI, 2006).

According to Campos (1994, cited by CASALI, 2006), the liberation of energy, or expansion by the dynamization method, does not occur in a linear way, but by leaps. When jumps are expansions within the same energy level, the manifestations remain similar to each other. In the case of expansions between levels, the manifestations change and the vibratory patterns become more and more subtle as the energy expands. Therefore, the body's response varies according to the homeopathic preparation and the potency used.

The same drug may be applicable to several organisms and to different situations, emphasizing the importance of the use of several dynamizations in experiments, since the responses may vary depending on the dynamization and the medicine under study (BONATO, 2007). In the inhibition of sporulation of the 
fungus, it was observed that the controls distilled water and mother tincture showed the same concentration of spores per milliliter $\left(5.5 \times 10^{5}\right)$. In the other treatments, when compared to these controls, there was a variable inhibition of sporulation according to the dynamization (Figure 1).

The index of mycelial growth velocity in the $27 \mathrm{CH}$ dynamization presented the highest mean (Table 1). However, in the rate of sporulation obtained a reduction of $49 \%\left(2.8 \times 10^{5}\right)$. After the $9 \mathrm{CH}$ there was a reduction of $45 \%$, which was one of the higher dynamics in the mycelial growth variables (Figure 1). This fact was also reported by Oliveira et al. (2011), who stated that not always the conditions that benefit the mycelial growth are the same ones found for sporulation, facts generally related to the composition of the medium.

Some dynamizations had an increase in sporulation capacity around $25 \%$ when compared to water and mother tincture, such as $3 \mathrm{CH}$ and $21 \mathrm{CH}$, with sporulation peaks of 6.8 and $7.0 \times 10^{5}$, respectively. When compared to the $30 \%$ hydroalcoholic solution, only $9 \mathrm{CH}$ and $27 \mathrm{CH}$ dynamizations apparently promoted a reduction in sporulation capacity of the fungus, around $27 \%$. However, dynamizations such as $3 \mathrm{CH}$ and $21 \mathrm{CH}$ raised their spore concentration per milliliter by more than 70\%. Most of the dynamizations $(3,15,21$ and $33 \mathrm{CH}$ ) benefited sporulation capacity.

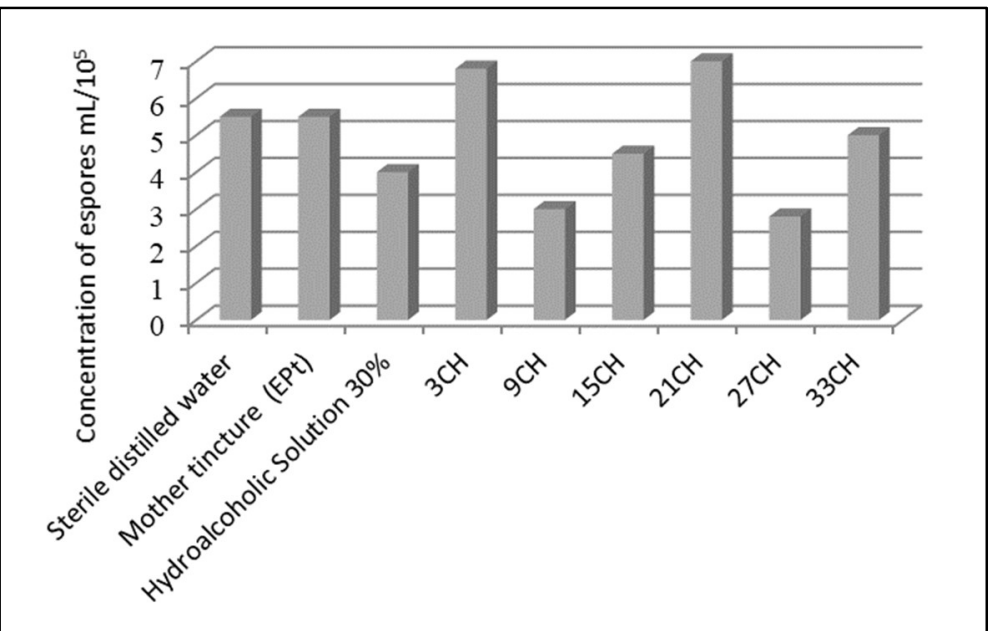

Figure 1: Sporulation (spores $\mathrm{mL}^{-1} \times 10^{5}$ ) of Colletotrichum gloeosporioides submitted to homeopathic treatment, on a Centesimal Hahnemanianna (CH) scale, of pyroligneousteak extract (Tectona grandis), after eight days of incubation.

Regarding the dynamization of spore germination (Table 1), there was no significant difference between treatments. Also verified that there was no differentiation between water and hydroalcoholic solutions with Propolis, Isotherapics, Ferrum sulphuricum, Sulphur, Phosphorus, Kali iodatum, Silicea terra and Staphysagria dynamics, all with germination rates above $92 \%$, with maximum reductions of $8 \%$. In this experiment, most of the dynamizations obtained averages higher than the controls distilled water and mother tincture, except $3 \mathrm{CH}$ that presented the highest rate of inhibition of germination (9\%). However, this dynamization was the one that most benefited the micelliation and sporulation, presenting the highest PRD average among all treatments, besides raising the spore production by about $70 \%$ when compared to the hydroalcoholic solution. Thus, the same dynamization acted to favor mycelial development (growth and sporulation) and did not benefit the germination capacity of $C$. gloeosporioides spores.

The $27 \mathrm{CH}$ and $33 \mathrm{CH}$ dynamizations, which presented low rates of PRD and sporulation rates, had the 
highest averages in spore germination (98 and 97\%, respectively). This behavior is described as a zig-zag effect by Espinoza (2001), which occurs when a substance in different dynamizations can reverse its effect for certain characteristics. Although there was no difference between the treatments used, all presented germination rates above $90 \%$, indicating low efficiency of the dynamizations in the control of $C$. gloeosporioides spores germination.

There was little or no fungitoxic effect of the pirolenous teak extract ( $T$. grandis), when applied dynamically in the in vitro tests. However, such results should not be taken as definitive to discard the use of this substance as homeopathic solution, because in field cultivation, these preparations will be applied in a situation of pathogen-host interaction, which may result in behavior different from that observed in this search. So it is fundamental, the development of other studies, analyzing different variables, dynamics, frequency and form of application.

\section{CONCLUSIONS}

In the conditions under which the experiment was developed, there is no fungitoxicity of the dynamizations of the pyroligneousextract of Tectona grandis, on the development and germination of the fungus Colletotrichum gloeosporioides.

\section{REFERENCES}

ALFENAS, C. A.; MAFIA, R. G.. Métodos em fitopatologia. Viçosa: UFV, 2007.

ANDRADE, F. M. C.; CASALI, V. W. D.. Homeopatia, agroecologia e sustentabilidade. Revista Brasileira de Agroecologia, v.6, n.1, p.49-56, 2011.

BEDENDO, I. P.. Grupos de Doenças: Classificação de doenças. In: AMORIM, L.; REZENDE, J. A. M.; BERGAMIN FILHO, A.. Manual de fitopatologia. Princípios e conceitos. Piracicaba: Agronômica Ceres, 2011. p.423-426.

BONATO, C. M.. Homeopatia na fisiologia do hospedeiro. Fitopatologia Brasileira, v.32, p.78-82, 2007.

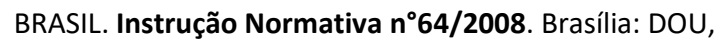
2008.

CARNEIRO, S. M. T. P. G.; ROMAN, E. D. B.; PIGNONI, E.; TEIXEIRA, M. Z.; VASCONCELOS, M. E. C.; GOMES, J. C.. Effect of biotherapic of Alternaria solani on the early blight of tomato-plant and the in vitro development of the fungus. International Journal of High Diluition Research, v.9, n.33, p.147-155, 2010.

CASALI, V. W. D.; CASTRO, D. M.; ANDRADE, F. M. C.; LISBOA, S. P.. Homeopatia: bases e princípios. Viçosa: UFV, 2006.

CASTRO, D. M.. Homeopathy: Principles and Applications. In: INTERNATIONAL CONFERENCE ON HOMEOPATHY IN AGRICULTURE, 2. Anais. Maringá: UEM, 2013.

ESPINOZA, F. J. R.. Agrohomeopatia: uma opcion ecológica para el campo mexicano. La Homeopatia de México, v.70, n.613, p.110-116, 2001.
FELITO, R. A.; YAMASHITA, O. M.; ROCHA, A. M.; GERVAZIO, W.; CARVALHO, M. A. C.; FERREIRA, A. C. T.; ROBOREDO, D.. Homeopathic treatments and their effect on the initial development of cucumber plants grown in cow manure contaminated by auxinic herbicide. Australian Journal of Basic and Applied Sciences, v.13, n.3, p.31-40, 2019a. DOI: http://doi.org/10.22587/ajbas.2019.13.3.5

FELITO, R. A.; YAMASHITA, O. M.; GERVAZIO, W.; CARVALHO, M. A. C.; ROBOREDO, D.; ROSSI, A. A. B.; SILVA, I. V.; DALLACORT, R.; SEABRA JUNIOR, S.. Homeopathy for treating contaminated cucumber seedlings with the herbicide residues. Journal of Agricultural Science, v.11, n.11, p.295-302, 2019b. DOI: http://doi.org/10.5539/jas.v11n11p295

FERREIRA, D. F.. Sisvar: a Guide for its Bootstrap procedures in multiple comparisons. Ciência e Agrotecnologia, Lavras, v.38, n.2, p.109-112, 2014. DOI: http://doi.org/10.1590/S1413-70542014000200001

GARBIM, T. H. S.; OLIVEIRA, J. P.; CORRER, C. J.; CERATTI, V. S.; LEONARDI, R.; ROMANO, E.; CARNEIRO, S. M. T. P. G. ; PIZA, S. M. T.; LONNI, A. A. S. G.. Avaliação do efeito de medicamentos homeopáticos sobre a germinação de esporos de Alternaria brassicicola e Corynespora cassiicola. In: ENCONTRO DE ATIVIDADES CIENTÍ́FICAS, 11. Anais. Londrina: UNOPAR, 2010.

KHANNA, K. K.; CHANDRA, S.. Control of tomato fruit rot caused by Fusarium roseus with homoeopathic drugs. Indian Phytopathology, v.29, n.3, p.269-272, 1976.

MACEDO, D .G. C.; DAVID, G. Q.; YAMASHITA, O. M.; 
CARVALHO, M. A. C.; SÁ, M. E.; LOURENÇO, F. M. S.; PERES, W. M.; MATEUS, M. P.B.; KARSBURG, I. V.; ARRUDA, T. P. M.; RODRIGUES, C.. Study of the control of fungus occurring in Schizolobium amazonicum seeds with the use of pyroligneous extract. International Journal of Plant \& Soil Science, v.31, n.4, p.1-9, 2019. DOI: http://doi.org/10.9734/IJPSS/2019/v31i430216

MARTíN, M. C.; GONZALES, C. E. F.; ALEMÁN, M.; MENESES, N.. Efecto de productos homeopáticos sobre hongos fitopatógenos en condiciones in vitro. Centro Agrícola. v.32, n.4, p.87-90, 2005.

MIYASAKA, S.; OHKAWARA, T.; NAGAI, K.; YAZAKI, H.; SAKITA, M. N.. Técnicas de produção e uso de fino de carvão e licor pirolenhoso. In: ENCONTRO DE PROCESSOS DE PROTEÇÃO DE PLANTAS: CONTROLE ECOLÓGICO DE PRAGAS E DOENÇAS, 1. Anais. Botucatu, 2001. p.161-176.

OLIVEIRA, J. A.. Efeito do tratamento fungicida em sementes no controle de tombamento de plântulas de pepino (Cucumis sativum L.) e pimentão (Capsicum annanum L.). Dissertação (Mestrado) - Universidade Federal de Lavras, Lavras, 1991.

OLIVEIRA, J. T. M.; BONALDO, S. M.; TRENTO, R. A.. Desenvolvimento de Colletotrichum sp. isolado de teca em diferentes meios de cultura. Enciclopédia Biosfera, v.7, n.13, p.1329-1334, 2011.

RODRIGUES, C.; SILVA, A. S. L.; SANCHES, I. J. R.; COSTA NETTO, L. F.; MESQUITA, J. S.; SILVA, M. S.; MATOS, D. L.; DAVID, G. Q.; MASSAROTO, J. A.; THEODORO, V. C. A.. Action of homeopathic doses of pyroligneous extract of teak (Tectona grandis) in Ceratocystis fimbrata development. In: INTERNATIONAL CONFERENCE ON HOMEOPATHY IN
AGRICULTURE, 2. Anais. Maringá: UEM, 2013.

ROLIM, P. R. R.; TOFOLI, J. G.; DOMINGUES, R. J.; ROSSI, F. Preparados homeopáticos no controle da pinta preta do tomateiro. Horticultura Brasileira, Brasília, v.23, n.2, 2005.

ROSSI, F.. Aplicação de preparados homeopáticos em morango e alface visando o cultivo com base agroecológica. Dissertação (Mestrado) - Universidade de São Paulo, Piracicaba, 2005

SANTOS, E. R.; MORANDI, M. A. B.; ALMEIDA, E. G.. Sistema para Contagem de Esporos Microbianos e Calibração de Suspensão (CALIBRA). Jaguariúna: Embrapa Meio Ambiente, 2011.

TOLEDO, M. V.. Fungitoxicidade contra Alternaria solani, controle da pinta preta e efeito sobre o crescimento do tomateiro (Lycopersicum esculentum Mill) por medicamentos homeopáticos. Dissertação (Mestrado) Universidade Estadual do Oeste do Paraná, Marechal Cândido Rondon, 2009.

TOLEDO, M. V.; STANGARLIN, J. R.; BONATO, C. R.;MIORANZA, T. M.; MULLER, M. A.; RISSATO, B. B.; LORENZETTI, E.; COLTRO-RONCATO, S.; KOSMANN, C. S.; ASSI, L.. Fungitoxicity activity of homeopathic medicines on Alternaria solani. African Journal of Agricultural Research, v.11, n.39, p.3824-3838, 2016. DOI: http://doi.org/10.5897/AJAR2016.11030

ZANETTI, M.. Uso de sub-produtos da fabricação de carvão vegetal na formação do porta-enxerto limoeiro 'Cravo' em ambiente protegido. Dissertação (Mestrado em Ciências Agrárias e Veterinárias) - Universidade Estadual Paulista, Jaboticabal, 2004.

A CBPC - Companhia Brasileira de Produção Científica (CNPJ: 11.221.422/0001-03) detém os direitos materiais desta publicação. Os direitos referem-se à publicação do trabalho em qualquer parte do mundo, incluindo os direitos às renovações, expansões e disseminações da contribuição, bem como outros direitos subsidiários. Todos os trabalhos publicados eletronicamente poderão posteriormente ser publicados em coletâneas impressas sob coordenação da Sustenere Publishing, da Companhia Brasileira de Produção Científica e seus parceiros autorizados. Os (as) autores (as) preservam os direitos autorais, mas não têm permissão para a publicação da contribuição em outro meio, impresso ou digital, em português ou em tradução. 